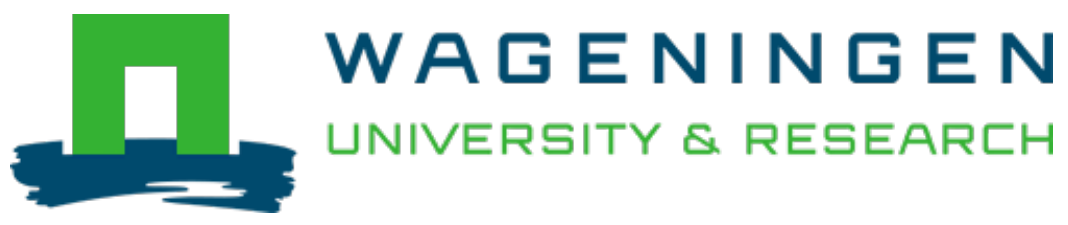

\title{
Advances in soilless culture of ornamentals
}

Advances in horticultural soilless culture

Kromwijk, J.A.M.; Os, E.A.

https://doi.org/10.1201/9781003048206-18

This publication is made publicly available in the institutional repository of Wageningen University and Research, under the terms of article $25 \mathrm{fa}$ of the Dutch Copyright Act, also known as the Amendment Taverne. This has been done with explicit consent by the author.

Article $25 \mathrm{fa}$ states that the author of a short scientific work funded either wholly or partially by Dutch public funds is entitled to make that work publicly available for no consideration following a reasonable period of time after the work was first published, provided that clear reference is made to the source of the first publication of the work.

This publication is distributed under The Association of Universities in the Netherlands (VSNU) 'Article $25 \mathrm{fa}$ implementation' project. In this project research outputs of researchers employed by Dutch Universities that comply with the legal requirements of Article $25 \mathrm{fa}$ of the Dutch Copyright Act are distributed online and free of cost or other barriers in institutional repositories. Research outputs are distributed six months after their first online publication in the original published version and with proper attribution to the source of the original publication.

You are permitted to download and use the publication for personal purposes. All rights remain with the author(s) and / or copyright owner(s) of this work. Any use of the publication or parts of it other than authorised under article $25 \mathrm{fa}$ of the Dutch Copyright act is prohibited. Wageningen University \& Research and the author(s) of this publication shall not be held responsible or liable for any damages resulting from your (re)use of this publication.

For questions regarding the public availability of this publication please contact openscience.library@,wur.nl 


\section{Chapter 15}

\section{Advances in soilless culture of ornamentals}

Erik van Os and Arca Kromwijk, Wageningen University \& Research, The Netherlands

1 Introduction

2 Growing systems for cut flowers: growing in rows

3 Growing in beds

4 Forcing of bulbs for cut flower production

5 Growing systems for pot plants

6 Phalaenopsis: a case study

7 Conclusions and future trends

8 Where to look for further information

9 References

\section{Introduction}

The cultivation of ornamentals, whether flowers and pot plants, is less widespread than vegetable production. The area used for ornamental cultivation is much less compared to the area used for vegetable production in most countries. Most production takes place conventionally in soil and soilless culture systems (SCS) are less often used. Research on the subject is limited, so specialists from different countries are consulted, depending on their expertise. For instance, Columbia is a leading producer of various types of flowers, whereas Ecuador specializes in the production of rose and exports products to the United States and Europe.

Where ornamentals are cultivated in soils, investment level is often low and traditional cultivation methods are only adapted slightly, depending on the exporter's preference in terms of variety and colour (pers. Comm. Nieves Garcia, WUR GH). As an example, carnation is sometimes grown in substrate beds. In North America, the United States shows developments in upscaling and increasing efficiency in cultivation, as well as using soilless growing methods, but many farms still grow in soil (pers. Comm. Chris Higgins, 2019). The key factor is the level of investment needed. In Kenya, Ethiopia and Uganda, for example, production mainly takes place in soil. The knowledge gap between growth in soil and in soilless conditions for staff is often too great and results 
in innovations in SCS being unsuccessful and in a return to traditional soilgrowing methods (pers. Comm. Nieves Garcia, WUR GH).

Fernández et al. (2018) has examined current trends in protected cultivation in Europe and highlighted how floriculture has begun to adapt new methods. European growers, for example, in the Netherlands, have developed SCS. In Spain, for example, SCS have been used to produce roses. SCS use $50 \%$ less water and $60 \%$ less fertilizer than soil (Van Os, 1998). However, the use of SCS is still limited by higher installation costs as well as by the greater technical skills and expertise required. Ornamental production is scattered throughout Europe. Begonia and azaleas are grown in container fields in Belgium (https:// Iv.vlaanderen.be/nl/voorlichting-info/publicaties/praktijkgidsen/water/ duurzaam-watergebruik-de-sierteelt.). In Denmark, pot plant production in greenhouses is popular and in Norway small greenhouses use artificial light to produce pot plants for the local market. Germany mainly produces pot plants and cut flowers for local markets. Italy also has large areas dedicated to producing container plants for export.

Countries such as Canada have developed governmental programmes for growers to be more efficient in the use of water. Deloitte (2009) and Zheng (2018) found that larger-scale growers use more ebb/flood and drip-irrigation techniques, and recirculate surplus water, compared to smaller-scale growers who use sprinkler irrigation. In Europe, traditional systems show the use of (movable) sprinkler irrigation while others have introduced the ebb and flood system for irrigation (Van Os, 2017). Water is sometimes recirculated but irrigation systems are mainly open systems. In the Netherlands, the area of ornamental production in greenhouses has always been comparable to that of vegetable production (Raaphorst, 2017). The Netherlands has 1000 ha in soil for cultivation of cut flowers such as chrysanthemums, lisianthus, lily and freesia, and about 2000 ha using pot plants. The area for roses has declined from about 900 ha to 250 ha. The area for ornamental cultivation is slowly decreasing, whilst the number of growers/companies is strongly decreasing (Raaphorst, 2017).

The change from soil to soilless cultivation started in the late 1970s with the introduction of the stone wool and nutrient film technique (NFT). Higher yields and better quality were achieved in vegetable cultivation. Problems with soil-borne diseases also stimulated a change to SCS. Roses suffered from nematodes and fungi in soils requiring soil to be disinfected via steam sterilization between cultivation cycles. Increasing energy prices between 1980s and 1990s also encouraged rose growers to change to soilless cultivation. The shift to SCS for flower crops was accelerated by the development of techniques for recirculation of nutrient solution along with the disinfection of recirculated drain water (Van Os, 1998, 2009).

In 2000, the EU Water Framework Directive (WFD, 2000) was introduced, which emphasized the importance of clean ground and surface water. In 
the Netherlands, it became a requirement for nutrient emissions and plant protection products (PPPs) to be reduced in surface water. Dutch governmental bodies and horticultural organizations agreed on reaching a zero nitrogen and phosphate emission rate by 2027 (Fig. 1). Southern European countries focussed on losses of water from greenhouses due to large levels of water consumption, while northern European countries were more aware of the polluting properties of nutrients and PPPs. All European countries are looking for more efficient use of water, partly because the supply of good quality water is limited and partly because pollution of ground and surface water needs to be avoided.

The discharge of nutrients in surface water (e.g. nitrates and phosphates) is seen as a problem but PPPs are also increasingly seen as a concern (Vermeulen et al., 2010; Van Ruijven et al., 2019; Beerling et al., 2014). In countries such as Belgium, Sweden and the United Kingdom, measures have been taken or considered to minimize the discharge of a nutrient solution with large amounts of nutrients and PPPs into surface water. New Dutch legislation requires growers to purify discharge water from soilless greenhouse cultivation to eliminate PPPs by 95\% (Van Ruijven et al., 2019). The idea of using a zero-liquid-discharge system has also been introduced (Van Os et al., 2019, 2020). A concern was why growers were discharging between $5 \%$ and $15 \%$ of their total annual water supply when the water was being recirculated (Fig. 2). The main reasons for discharges were the fear of a high sodium concentration and an unbalanced composition of the nutrient solution. More and more growers are trying to become a 'zero-discharger'. If a grower can prove he is not discharging any nutrient solution containing PPPs, he will be approved as a zero-discharger and therefore does not need to invest in purification equipment.

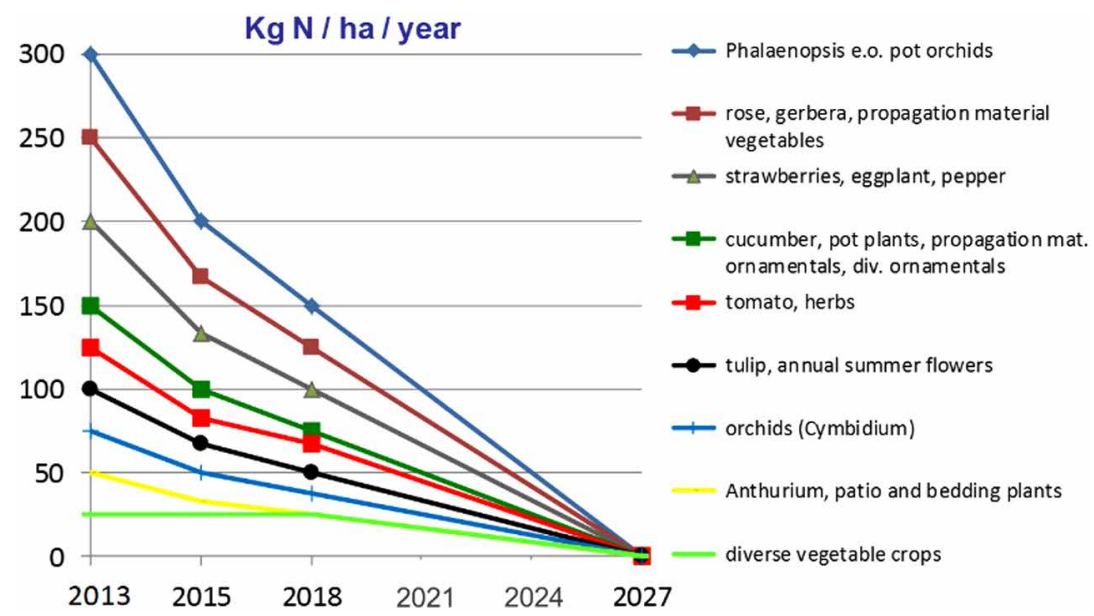

Figure 1 Nitrogen emission standards for soilless grown crops in the Netherlands (Activiteitenbesluit Landbouw, 2013 and 2018). 


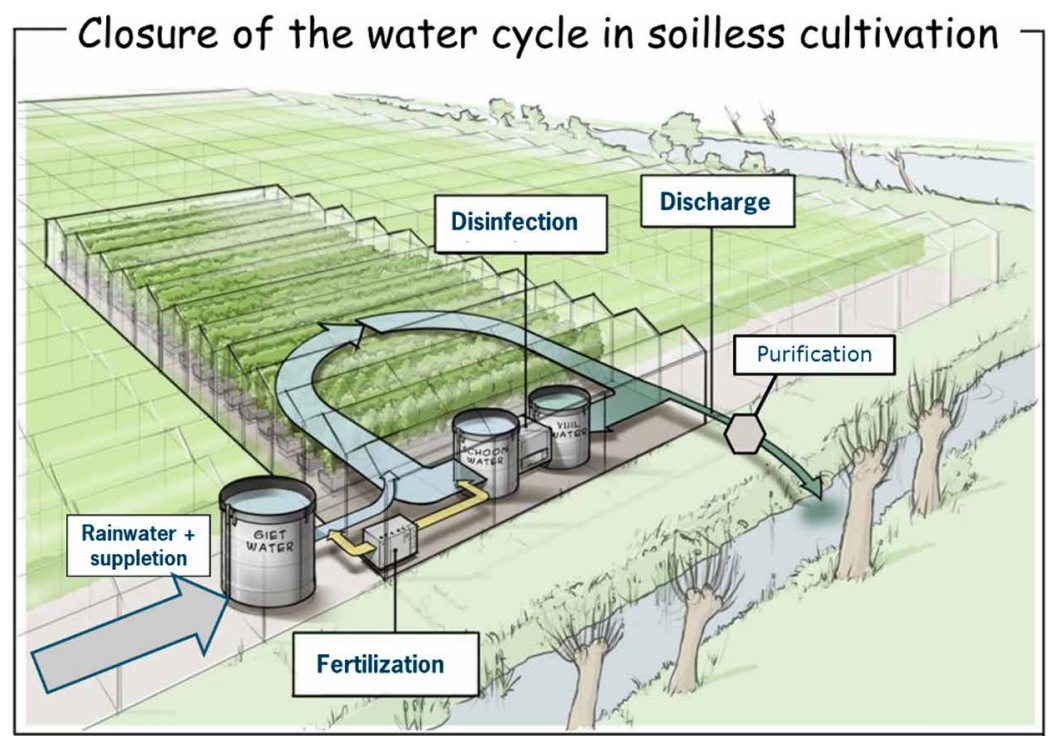

Figure 2 Schematic overview of the water flows at a Dutch farm.

\section{Growing systems for cut flowers: growing in rows}

Various growing systems are used in soilless ornamental production. This section provides an overview of the systems used, adaptations and challenges for the future, starting with cut flowers. The large variation in cut flowers also resulted in many types of systems. Basic groups are (Van Os et al., 2019):

- Rose, gerbera and cymbidium growing in rows; 5-10 plants $/ \mathrm{m}^{2}$.

- Anthurium, amaryllis, gypsophila, bouvardia, carnation, alstroemeria and lily growing in beds of 120-140 cm wide, 20-40 plants $/ \mathrm{m}^{2}$.

- Chrysanthemum, lisianthus, freesia and aster mainly growing in soil, 40-80 plants $/ \mathrm{m}^{2}$.

- Forced bulb flowers, such as tulip, hyacinth and iris grown in ebb and flood systems without any substrate.

This section discusses growing in rows. Other systems are discussed in the following sections.

Rose- and gerbera-growing row systems are comparable with vegetable systems (Fig. 3). The system is based on a cultivation period of more than one year (rose 3-5 years; gerbera 2-3 years) and the almost daily need to check plants to harvest the flowers. Rose cuttings are rooted in stone wool or coir blocks and transplanted to slabs of the same material. Slabs lie in long rows behind each other on about $0.2 \%$ sloped troughs. They are placed in greenhouses in a support system in the soil. The height above the soil made 

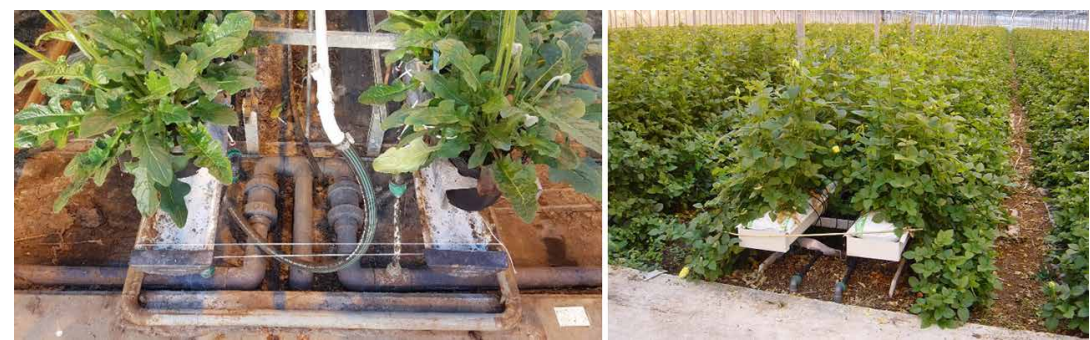

Figure 3 Gerbera in a rack system to fix containers filled with coir or rockwool cubes (left). Rose growing in a bent cane system (right).

the bent cane system possible, producing more roses of better quality (Fig. 3). Irrigation takes place by drip lines with pressure-compensated drippers of 2 L/h. Surplus supply water (drain water; $30-50 \%$ of the supply) is collected in troughs and flows on gravity to a drain water collection tank to be pumped out of the greenhouse to be disinfected and reused again. The distance between the troughs depends on plant density requirements of the crop as well as the stands and span width of the greenhouse construction.

Young gerbera plants are placed on slabs of stone wool or coir or in containers of about $20 \mathrm{~cm}$ diameter filled with stone wool cubes or coir (Fig. 3). In the same way as roses, slabs are placed in troughs with drip irrigation and the drain water is recirculated. If planted in containers, a rack system is often used to keep the containers well-balanced and to avoid pulling the plants out of the substrate during harvesting. A trough is placed below the containers. In the case of both rose and gerbera, growth in separate acclimatized compartments has been shown to improve yields (Van Weel, 2005). However, high annual costs and problems with the irrigation system have not made these systems commercially feasible (Van Tuijl et al., 2005). New varieties and the use of artificial lighting, as well as zero-liquid discharge systems, have also improved the efficiency of SCS.

\section{Growing in beds}

Many flower crops are cultivated in beds, as the plant density is much higher (20-40 plants $/ \mathrm{m}^{2}$ ), compared to rose and gerbera (5-10 plants $/ \mathrm{m}^{2}$ ).

\subsection{Anthurium}

Anthurium for cut flower production has been grown in soilless systems for a few decades. The system uses a bed with containers filled with a substrate with a high bulk density $\left(>500 \mathrm{~kg} / \mathrm{m}^{3}\right)$. Clay or lava granulate is widely used. A lighter substrate causes turnover of the plants after a few years of cultivation; long and heavy shoots develop outside the container. It is also possible to grow the 
plants directly in a bed filled with lava or clay granulates. In the middle of each $120 \mathrm{~cm}$ wide bed lies a drainage pipe to collect the surplus of nutrient solution to be recirculated.

\subsection{Amaryllis (Hippeastrum)}

Amaryllis (Hippeastrum) cultivation uses two systems. The growing of bulbs takes mainly place in soil, but the forcing of flowers is now changing to a soilless system, primarily due to an increasing problem with Fusarium and nematodes (Kromwijk et al., 2016). Perlite and clay granulates are the main substrates (Fig. 4). As bulbs are big, a loose substrate layer of $5-15 \mathrm{~cm}$ is popular. Cultivation takes 3-4 years after which bulbs are renewed. Bulbs are planted in beds of 120-140 cm wide, with a drain pipe in the middle. Growers were reluctant to recirculate the nutrient solution because of the release of toxic plant root exudates.

Kromwijk et al. (2016) have compared disinfection of drain water with UV light, with combined UV light and hydrogen peroxide (advanced oxidation) for break-down of the root exudate lycorine. During the three-year trial there were no differences in production and crop growth, although growth of the roots in the control was slightly less. Van Marrewijk (2012) found lycorine as potential toxic root exudate with high concentrations of $68 \mathrm{mg} / \mathrm{kg}$ fresh weight in the bulb itself and lower concentrations in the roots, with an average $4.5 \mathrm{mg} / \mathrm{L}$. Further experiments showed no presence of lycorine in drain water in soilless cultivation of amaryllis. Lycorine is not broken down by heat treatment $\left(95^{\circ} \mathrm{C}\right)$, but a high UV light dosage $\left(240 \mathrm{~mJ} / \mathrm{cm}^{2}\right)$ is effective. It means that, with reuse of drain water, UV light is the better disinfection method.

After cultivation for 3-4 years, the substrate has to be renewed or disinfected. Normally steam sterilization is used in soil. In substrate beds, which are rather dry, steam sterilization is also possible if all synthetic materials are resistant to temperatures of more than $90^{\circ} \mathrm{C}$. Another option is to remove the
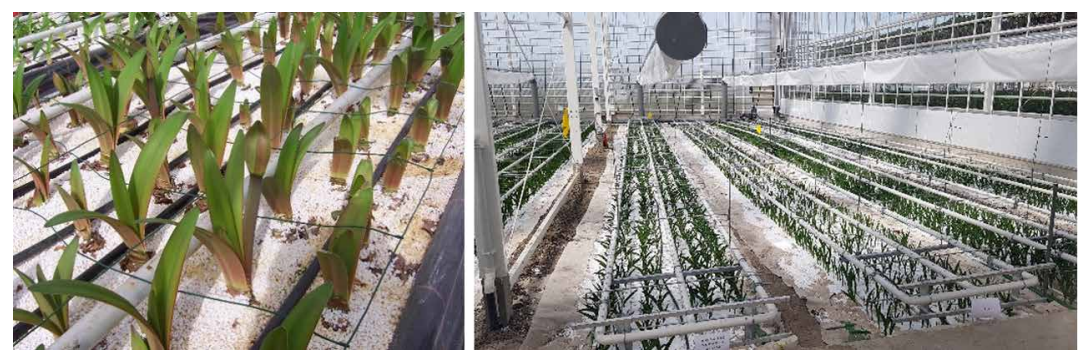

Figure 4 Amaryllis in perlite (left), and Freesia in sand beds (right) with a polystyrene cover for light reflection. 
substrate and to refill the system with a fresh, unused substrate, which is not very much done. Both are being investigated in practical trials by the growers.

\subsection{Freesia}

Freesia is a tuber crop which produces flowers in 5-7 months and where after the corms stay in the soil to grow further for a short period. After digging them up, corms are dried and receive a high temperature treatment during storage. They are then replanted and after 2-3 weeks soil temperature is changed to about 16 to induce flowering and produce new flowers. During the last ten years, a few experiments have taken place to a soilless system with sand as a substrate (Fig. 4). Flower production was improved (Blok \& Kromwijk, 2014a) but corm quality was not sufficient to be reused in new cultivations.

Better results are achieved if the sand layer has a uniform thickness. An anti-root foil is used below the sand. Below that a drainpipe is used to collect the drain water, lying in a layer of clay granulates. All foils must be resistant to steam sterilization $\left(90-100^{\circ} \mathrm{C}\right)$. Blok and Kromwijk (2014a) compared 10 substrates for growing freesia and concluded that coarse coir or coarse peat resulted in better growth, possibly due to high air content at saturation level. However, too many roots are formed in coir while, in substrates as perlite and lava granulates, it is difficult to separate tubers $(1-3 \mathrm{~cm})$ from substrate granules with the same size.

\subsection{Chrysanthemum and lisianthus}

Chrysanthemum is still mainly grown in soil in the Netherlands. Van Os (1980) reported a fully mechanized system using a NFT with flat troughs of $3-5 \mathrm{~cm}$ wide as the rooting block. While cultivation was successful, the system did not prove economically feasible. Later the 'mobysant' project was launched in which bare-rooted cuttings were placed in coir in $6 \mathrm{~cm}$ troughs (Van Os, 2006). The troughs were on a $0.5 \%$ slope and drain water was collected and reused. The main problem was the combination of a substrate and NFT which caused too many dry and wet spots in the trough and substrate and, consequently, a much higher risk for Pythium. This meant that fewer than $90 \%$ flowers from the planted cuttings could be harvested and, consequently, the system was not economical. Similar results were reported by Vermeulen (2009). The combination of substrate and a hydroponic system such as NFT and DFT is harder to manage and causes higher risks of diseases such as Pythium. Another development is bare rooting of the cuttings (Van Winsen, 2015; Dodde, 2017; Glastuinbouw Nederland, 2019). Results are promising after 4 years though economic feasibility has to be proven and a solution has to be found for transport of bare-rooted cuttings to final planting. Bare-rooted cuttings cannot 
survive a long time out of the solution. Either propagation needs to take place at the grower stage or transport has to be reorganized. Overviewing all the experiments in producing chrysanthemums, it clearly takes a number of years to become familiar with a system to get maximum growth. It is also important that the system should always be economical for the grower. Economic feasibility is challenging, particularly given further improvements in soil cultivation (e.g. faster growing cycles, higher yield and quality).

Lisianthus has been grown on NFT systems on a semi-practical scale, for example, in coir with sub-irrigation (ebb/flood) (Van Velden, 2014). Drip irrigation did not work because of uneven water content of the coir substrate with more than 40 plants per $\mathrm{m}^{2}$. The high sensitivity for fungal diseases requires frequent disinfection of circulating water and substrate (Sleegers, 2013). The system is not yet feasible technically or economically, but progress is being made.

In general it is difficult to make a substrate system with more than 40 plants per $\mathrm{m}^{2}$ economic. The use of drip irrigation for each plant is too expensive and handling at planting and harvesting stages is not practical. Applying one dripper for 4 or 8 plants mostly gives uneven growth. These types of crops often have a short rotation with 4-6 plantings per year. Drippers have to be removed after harvest and replaced. The substrate also has to be tilled, otherwise a heterogenic substrate develops because cuttings are rooted in substrate (mainly peat) blocks which stay behind after each harvest.

\section{Forcing of bulbs for cut flower production}

Tulips, hyacinth and iris are examples of crops where bulb production takes place in the open field, while forcing takes place in a one-layer or a multi-layer SCS on NFT or ebb/flood in a greenhouse from January to May. Bulbs grow for the entire season in the soil and are dug up in autumn. They are cooled under specific temperature conditions after which they can be forced. Bulbs are placed in special trays (Fig. 5) to keep them straight up, especially needed when
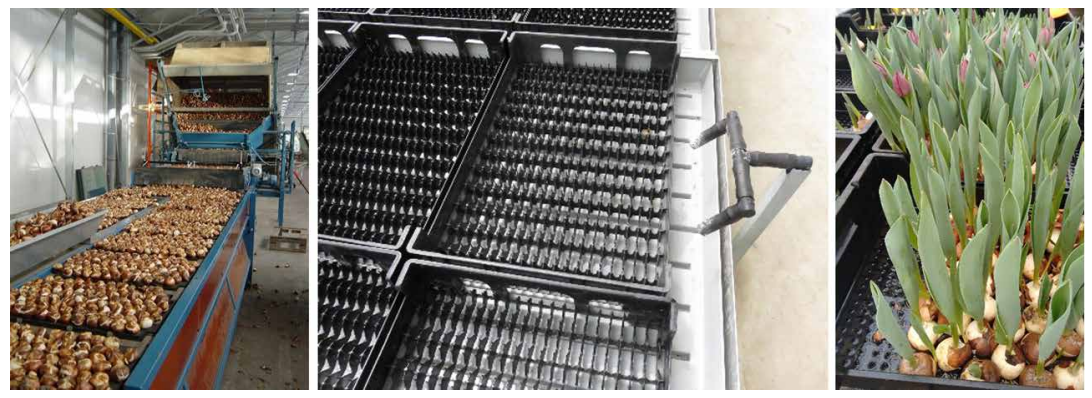

Figure 5 Tulip bulbs are pricked in trays by hand (left); empty trays for pricking bulbs on the ebb/flood irrigation tables (middle); forced tulips in greenhouse (right). 
the heavy flower appears and turnover during transport of the trays is a risk. The trays are placed on tables for a period of about 3 weeks. One system consists of three stacked layers. First, the lowest layer without artificial light is planted with the first signs of the flowers emerging from the bulbs. The final ripening of the flowers takes place at the upper layer at the top of the greenhouse. Growing tables can be automatically moved from the working shed to the greenhouse and back. The total water system is a recirculating system with disinfection of the nutrient solution with UV or ozone. In another system, only one layer of tables is used in the greenhouse. Growing tables are also planted and harvested in the work shed.

\section{Growing systems for pot plants}

Small flowering pot plants (e.g. kalanchoe, cyclamen, pot chrysanthemum, begonia, saintpaulia, phalaenopsis and many others) grow in 8-12 cm pots on ebb/flood tables or benches, have a short growing cycle and require substantial labour (Fig. 6). The tables can be fixed to one location, rolling from left to right in the same span or automatically transported from the work shed to the greenhouse and back. Large foliage pot plants, such as palms, ficus, monstera, dracaena and others, grow often on concrete floors in pots of 15-30 cm (Fig. 6). Machinery to place and collect the containers can operate on concrete floors. Plants require little labour but need a long cultivation time. Irrigation is mostly done by ebb/flood. Nutrition of the plants is done via the fertigation system, adapting to the growing needs of plants. Alternatively, controlled release fertilizers can be used directly when young plants are potted up. There are big differences in automation. Some growers place the plants by hand on the tables. Others use specific rakes to pick up one row of 10-15 plants. Such rakes are also able to space the plants from about $3 \mathrm{~cm}$ to $10-15 \mathrm{~cm}$. Large-scale growers automate all handling from filling the pots and placing on the tables in the work shed to transport of the tables to the greenhouse. In some countries, such as The Netherlands, image analysis is already standard to grade plants by size or colour. In addition, automated detection of insects and fungi will be commercially available in the next few years.
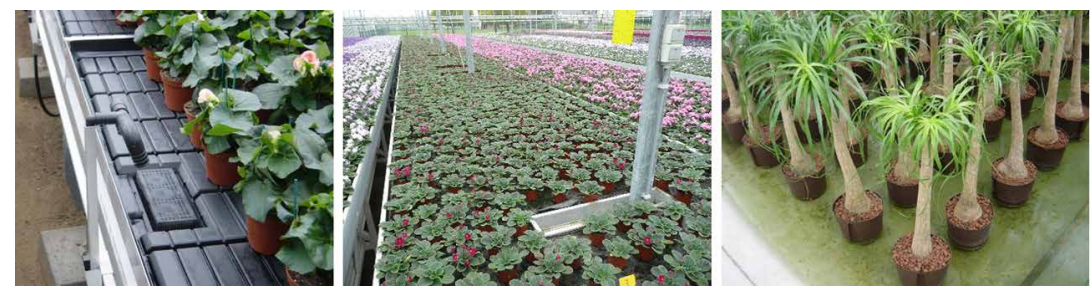

Figure 6 Pot plants on ebb/flood tables (left and middle) and on a concrete floor in clay granulates (right). 
Outdoor production of container plants, such as azalea, heath (Erica species), nursery stock and begonia, also takes place on floors. Sprinkler irrigation from above is normal, with ebb/flood the exception. To recirculate surplus water the water needs first to be filtered and preferably disinfected. An additional problem is rain and snow. Rainwater should be collected from a closed floor to be used first, but the installation needs adaptation to discharge a certain volume of water to surface water.

\section{Phalaenopsis: a case study}

Phalaenopsis is an orchid grown in pots. It is one of the most important pot plants in the Netherlands (Kromwijk et al., 2019) with a turnover in 2016 of $€ 500$ million which is $33 \%$ of the total annual pot plant turnover (Royal Flora Holland, 2016). The production area was more than 250 ha in 2016 (Raaphorst, 2017). The plants were grown on open bottom tables and irrigated from above with sprinklers. Dutch legislation followed the EU Water Framework Directive (WFD, 2000) which favoured phalaenopsis cultivation. Recirculation was not needed because of sodium sensitivity and very limited use of fertilizer (Van Os, 1998; Beerling et al., 2017). Once production techniques were well-established, there was a dramatic increase in production area which was followed by a fall in prices.

A phalaenopsis pot plant requires a vegetative period of 28 weeks with high temperatures $\left(28^{\circ} \mathrm{C}\right)$, followed by a generative period of about 18 weeks with lower temperatures (about $19-22^{\circ} \mathrm{C}$ ). At this point the use of fertilizers is increased from an electric conductivity (EC) of 0.5 or less in the past to about $1.5 \mathrm{mS} / \mathrm{cm}$ now. Under new environmental legislation (Fig. 1) phalaenopsis was placed in the group where most emission of nitrogen was allowed compared to other crops. It also became clear that growers had to change their growing system towards a recirculation system. An enquiry among 30 growers highlighted their main concerns (Schoenmakers, 2012). These included: presence of sodium, dispersal of root-borne pathogens and imbalances in nutrient composition.

Traditionally phalaenopsis has been grown in an open-loop system. Based on Baas (2010) the estimated transpiration is on average $0.6-1.1 \mathrm{~mm} /$ day. This is about 2000-4000 m³/ha/year. As water supply is once in 4-6 days $10-15 \mathrm{~L} / \mathrm{m}^{2}$ with a drain percentage of $70 \%$ it was calculated that between 4300 and $9600 \mathrm{~m}^{3}$ /ha/year was supplied to the crop (Van Os and Kromwijk, 2014a). When the nutrient solution contains $15 \mathrm{mmol} / \mathrm{L}$ it can be calculated that between 900 and $2000 \mathrm{~kg} \mathrm{~N}$ per ha per year is discharged to ground or surface water or the sewage system. This is much more than the earlier expected discharge of $300 \mathrm{~kg} / \mathrm{ha} /$ year, which is comparable with $1400 \mathrm{~m}^{3} / \mathrm{ha}$ /year (Van Os and Kromwijk, 2014b). This means a closed-loop system is required. Growers have 
had to invest in collecting drain water below the mesh tables, such as drain water storage, filters, disinfection equipment, pumps and pipework. It would also be useful to separate the water circuits in the vegetative and generative growth periods to be able to supply a different EC of the nutrient solution.

Systems used are mostly open mesh tables with galvanized wire bottoms on which 9-15 cm pots are placed. The pots contain a bark substrate (Fig. 7). The surplus water drains through and between the pots and through the wire mesh to the soil. Several growers have placed a $1.0-1.5 \mathrm{~mm}$ liner beneath the tables. However, zinc concentrations became too high. Zinc is required in the nutrient solution (2-5 $\mu \mathrm{mol} / \mathrm{L})$. In most crops values of more than $25 \mu \mathrm{mol} / \mathrm{L}$ give toxicity symptoms which often looks like iron deficiency (yellowness in the young leaves) (Blok and Kromwijk, 2014b). The cause of this problem is the use of galvanized mesh growing tables. Now growers are gradually transitioning to a closed-loop system. A watertight floor is used with a drainpipe lying in lava granulates to collect the surplus solution. Mesh tables are placed on this. A further future development could be the use of aluminium mesh tables or a closed polyester-profiled bottom, similar to pot plants. The surplus can then be collected, disinfected and reused.

In SCS it is mostly recommended to avoid the use of urea, $\mathrm{CO}\left(\mathrm{NH}_{2}\right)_{2^{\prime}}$ because urea does not increase the $\mathrm{EC}$ value of the nutrient solution but does decrease its $\mathrm{pH}$-value. In open-loop systems, growers usually use a nutrient solution with a concentration of $1.0 \mathrm{dS} / \mathrm{m}$ and $3.5 \mathrm{mmol} / \mathrm{L}$ urea which is similar to $7 \mathrm{mmol} \mathrm{N}$ and $0.7 \mathrm{EC}$. An EC of $1.7 \mathrm{mS} / \mathrm{cm}$ is supplied to the plants (Blok and Kromwijk, 2015). To realize the same ion concentration in the root environment, the bivalent ions $\mathrm{Ca}$ and $\mathrm{Mg}$ should be lowered and the monovalent ion $\mathrm{K}$ has to be increased when changing from an open-loop system to a closedloop system. Current advice is to use an EC of $1.2 \mathrm{mS} / \mathrm{cm}$ in the open-loop system and $1.3 \mathrm{mS} / \mathrm{cm}$ in the recirculation system in the vegetative stage, which changes to $1.1-1.3 \mathrm{mS} / \mathrm{cm}$ (open/closed) in the generative stage. K/Ca changes from 1.5 in open system to 2.7 in closed system in the vegetative stage, while in the generative stage it changes from 2.1 to 3.0 .
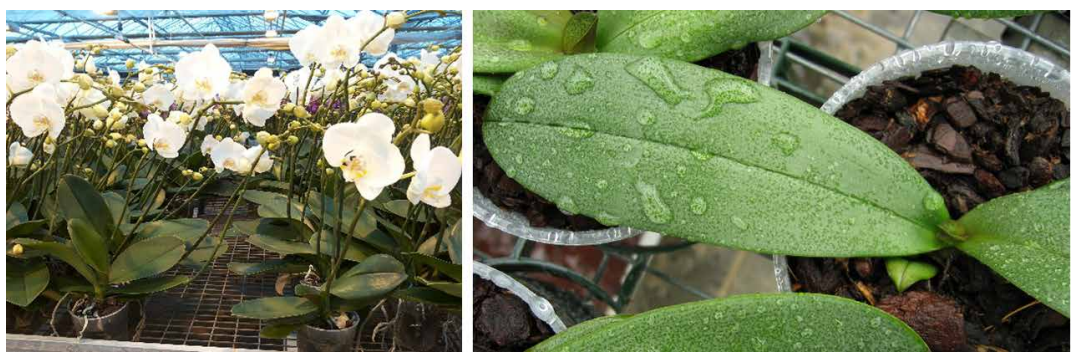

Figure 7 Phalaenopsis on open-growing tables (left) and after sprinkler irrigation (right) in the vegetative growth period. Bark is used as substrate. 
Kromwijk et al. (2019) compared the reuse of the nutrient solution with an open run-to-waste system on traditional mesh tables and sprinkler irrigation. Results showed $70 \%$ drainage in open systems, compared to $30-50 \%$ in closed systems of vegetable and cut flower production. The increase in EC in drain water was limited $(0.2 \mathrm{mS} / \mathrm{cm})$. Before recirculation, drain water was disinfected by UV treatment. In the open system $>1500 \mathrm{~kg} \mathrm{~N}$ per ha was discharged. In the two recirculation treatments $182 \mathrm{~kg} \mathrm{~N} / \mathrm{ha}$ was discharged at a sodium concentration of $1.2 \mathrm{mmol} / \mathrm{L}$ and $96 \mathrm{~kg} \mathrm{~N} / \mathrm{ha}$ was discharged due to an unbalanced nutrient solution. In all treatments the same production and quality was achieved. It could be concluded that if good-quality rainwater is used, recirculation is possible and discharge of nitrogen is dramatically decreased. Sodium does not accumulate very rapidly (e.g. a threshold value of $2 \mathrm{mmol} / \mathrm{L}$ looks possible) (Kromwijk et al.,2017), but has to be proven for phalaenopsis.

\section{Conclusions and future trends}

The need to be more efficient with water supply is an important step in greenhouse horticultural development. There is a change from soil to SCS and, within soilless systems, from open, run-to-waste systems to closed-loop systems. The first step is to move from a closed system with a minor 5-10\% discharge to a zero liquid discharge. This means that all water used stays in the system and there is no discharge of water, nutrients and PPPs to sewage, ground or surface water. However, this requires significant investment in both technology and expertise.

In ornamental production there is a slow change to SCS. In some European countries, such as in the Netherlands, legislation is the steering factor. The established crops grown using soilless systems (rose, gerbera) are looking to zero liquid discharge, while the traditionally soil-grown crops are looking for economically feasible systems to avoid discharge to the environment. For amaryllis (Hippeastrum) the change looks promising but, for other crops such as freesia, chrysanthemum, and lisianthus, there is still a long way to go.

Phalaenopsis, the leading pot plant crop in the Netherlands, had to make a big change. Initially legislation did not require recirculation and an open system was accepted. During the last 15 years improvements in cultivation led to increased use of fertilizers resulting in unacceptably high discharges of nitrogen, requiring a transition to a closed system. The fear of sodium accumulation became reality and, consequently, clean fresh and/or rainwater had to be used, while large investments were required to recirculate the nutrient solution.

As the world faces increasing shortages of water, water-use efficiency in the cultivation of ornamentals needs to be further improved. In several European countries there is the desire to avoid discharge of nitrogen and PPPs. In the Netherlands a zero liquid discharge of nitrogen should be achieved by 2027 


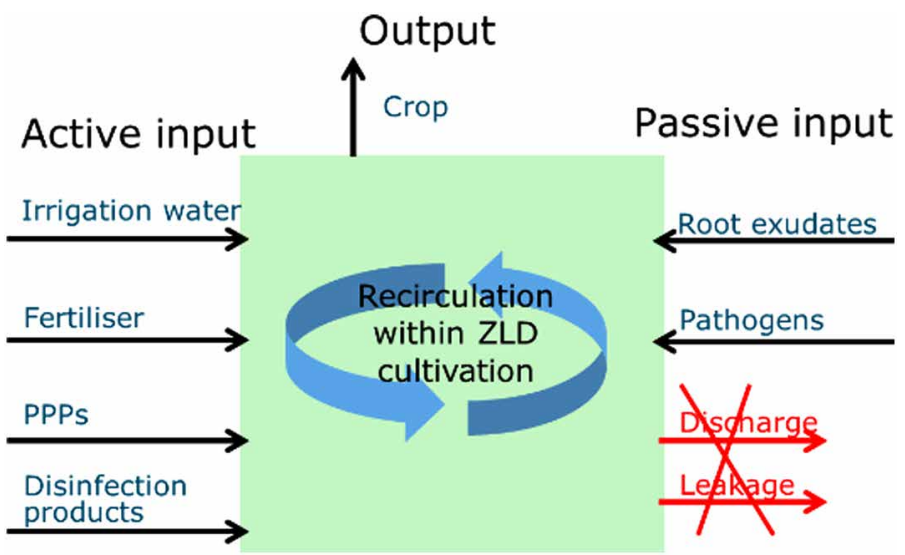

Figure 8 Keeping the balance in a zero-liquid discharge growing system.

while, since 2018, growers have had to purify discharge water to eliminate PPPs by $95 \%$. Gerbera and pot plant growers have shown how to achieve a zeroliquid discharge (Van Ruijven et al., 2019; Van Os et al., 2019, 2020). As shown in Fig. 8 a good balance in the water system is essential. Inputs in the system have to be taken up by the plant or broken down. This applies to fertilizers and to pipework-cleaning products such as bleach, chlorine products and hydrogen peroxide, as well as so-called growth improvers to improve plant resilience against diseases. However, it is most essential to start with sodiumfree and pathogen-free water supply.

The change to SCS is likely to increase because it is easier to prevent disease and water- and fertilizer-use efficiencies are much better and, consequently, yield and quality of the produce are higher. However, higher initial investment and lack of knowledge remain as barriers to change. Another tendency is the upscaling of the sector as small companies are acquired by larger businesses. Because of the larger scale, the investment level can be increased, for example, in better irrigation systems to increase water-use efficiency (Zheng, 2018; Raaphorst, 2017). Governmental bodies can steer these improvements by legislation but they also need to offer subsidies for environmentally friendly investments in technology.

\section{Where to look for further information}

- International Society for Horticultural Science, ISHS: www.ishs.org. The leading organization for all horticultural sciences which are reported in symposia and the Acta Horticulturae proceedings.

- The technical magazine for growers ('Onder Glas') has also an English issue: https://www.ingreenhouses.com/. Magazines can be read online for 
free, but with a delay of months, or a paid subscription. It gives information about the latest results in research and commercial development for the entire greenhouse sector, especially meant for growers.

- Wageningen University and Research, Business Unit Greenhouse Horticulture with English website and all news on greenhouse horticulture including scientific reports. https://www.wur.nl/en/Research-Results/R esearch-Institutes/plant-research/greenhouse-horticulture.htm

\section{References}

Activiteitenbesluit Landbouw, 2013. Ministry of Infrastructure and Environment, 01-012013. lenM/BSK-2012/233271 (in Dutch), p. 14. Available at: www.rijksoverheid.nl (revision 2018).

Baas, R., 2010. Verdampingsmodel Phalaenopsis. Report Productschap Tuinbouw, 33p (in Dutch).

Beerling, E., Van Os, E. A., Van Ruijven, J., Janse, J., Lee, A. and Blok, C., 2017. Waterefficient zero-emission greenhouse crop production: a preliminary study. Acta Hortic. 1170, 1133-1140.

Beerling, E. A. M., Blok, C., Van der Maas, A. A. and Van Os, E. A., 2014. Closing the water and nutrient cycles in soilless cultivation systems. Acta Hortic. 1034, 49-56.

Blok, C. and Kromwijk, J. A. M., 2014a. Freesia op substraat: praktijkproeven 2013 en 2014. (Rapport / Wageningen UR Glastuinbouw; No. 1309), 22p. Bleiswijk: Wageningen UR Glastuinbouw (in Dutch).

Blok, C. and Kromwijk, J. A. M., 2014b. Recirculatie potorchidee. Flyer no. 5, Zink. Available at: https://www.glastuinbouwwaterproof.nl/content/3Onderzoek/Recirculatie_potorc hidee/5_Flyer_Zink.pdf (in Dutch).

Blok, C. and Kromwijk, A., 2015. Recirculatie potorchidee. Flyer no. 9, Nieuw voedingsschema phalaenopsis (in Dutch).

Deloitte, 2009. The impact of ornamental horticulture on Canada's economy. Report Deloitte and Touche, 138p.

Dodde, H. 2017. Chrysanten laten zich goed telen op water. Nieuwe Oogst, 24 October 2017. Available at: https://www.nieuweoogst.nl/nieuws/2017/10/24/chrysanten -laten-zich-goed-telen-op-water (in Dutch).

Fernández, J. A., Orsini, F., Baeza, E., Oztekin, G. B., Muñoz, P., Contreras, J. and Montero, J. I., 2018. Current trends in protected cultivation in Mediterranean climates. Eur. J. Hortic. Sci. 83(5), 294-305. ISSN 1611-4426 print, 1611-4434 online | ( ISHS 2018.

Glastuinbouw Nederland, 2019. Chrysant op water is ook nieuw leren telen. Available at: https://www.glastuinbouwnederland.nl/nieuws/chrysant-op-water-is-ook-nieuwleren-telen/ (in Dutch)

Kromwijk, A., Blok, C., van Os, E. A. and Beerling, E., 2019. Reusing drainwater to lower the emission of nutrients in the cultivation of phalaenopsis. Acta Hortic. 1262, $101-$ 108. DOI: 10.17660/ActaHortic.2019.1262.15

Kromwijk, A., Voogt, W., Steenhuizen, J., van Winkel, A. and van Mourik, N., 2017. Natriumgevoeligheid en recirculatie bij Cymbidium in 3 teeltjaren: Behoud plantgezondheid en voorkomen groeiremming bij hergebruik drainwaterdrain water. Bleiswijk: Wageningen University \& Research, BU Greenhouse Horticulture. (Rapport WPR; No. 735), 54p. doi: 10.18174/433587. 
Kromwijk, J. A. M., van der Burg, R., Nijs, L., Overkleeft, J., Eveleens-Clark, B. A., Blok, C., Woets, F., 2016. Recirculatie bij snij-amaryllis (Hippeastrum) in drie teeltjaren (2013-2015): Behoud plantgezondheid en voorkomen groeiremming bij hergebruik drainwater. (Rapport GTB; No. 1398), 88p. Bleiswijk: Wageningen UR Glastuinbouw (in Dutch).

Raaphorst, M. G. M., 2017. Kwantitatieve Informatie Glastuinbouw 2016-2017. Bleiswijk: Wageningen University \& Research, BU Greenhouse Horticulture (in Dutch).

Royal Flora Holland, 2016. Jaarverslag 2016. Available at: https://viewer.onlinepublisher .nl/flora-holland-jaarverslag-2016-nl (in Dutch).

Schoenmakers, M., 2012. Inventarisatie knelpunten emissiebeperking pot-orchideeën. Eindrapportage LTO Groeiservice PT 14263-28. Available at: https://www.glastuin bouwwaterproof.nl/content/3Onderzoek/Knelpunten_emissiebeperking_potor chidee.pdf (in Dutch).

Sleegers, J. 2013. Lisianthus uit de grond heeft nog eind te gaan. Vakblad voor de Bloemisterij, 12, 34-35. Available at: https://proeftuinzwaagdijk.nl/publicaties/Lis ianthus\%20uit\%20de\%20grond\%20heeft\%20nog\%20eind\%20te\%20gaan.pdf

Van Marrewijk, I., 2012. Amaryllis, gaat recirculatie samen met een gezond gewas? Report Horticultural Board, PT 146660 (in Dutch).

Van Os, E. A., 1980. Complete mechanization of the growing of cut chrysanthemums in nutrient film. In: ISOSC Proceedings Fifth Congress, Wageningen, the Netherlands, pp. 187-196.

Van Os, E. A., 1998. Closed soilless growing systems, the finishing touch. Acta Hortic. 458, 279-289.

Van Os, E. A., 2006. Mobysant: meer dan 28\% energiebesparing per tak is mogelijk. Onder Glas. 3(1), 44-45 (in Dutch).

Van Os, E. A., 2009. Comparison of some chemical and non-chemical treatments to disinfect a recirculating nutrient solution. Acta Hortic. 843, 229-234.

Van Os, E. A., 2017. Recent advances in soilless culture in Europe. Acta Hortic. 1176, 1-8.

Van Os, E. A., Beerling, E. A. M., Blok, C., Janse, J., Leyh, R., van Ruijven, J. P. M., van der Staaij, M. and Kaarsemaker, R., 2019. Zero discharge of nutrients and pesticides to the environment in hydroponic production. Acta Hortic. 1266, 443-450.

Van Os, E. A., Beerling, E. A. M., Blok, C., Leyh, R., van Ruijven, J. P. M., van der Staaij, M., Janse, J., Kaarsemaker, R. and Roosen, W., 2020. Zero liquid discharge in soilless greenhouse horticulture: solutions to save water and the environment while ensuring an optimal production. Acta Hortic. 1273, 129-135.

Van Os, E. A. and Kromwijk A., 2014a. Recirculatie potorchidee. Flyer 7, Watervoorziening. Available at: https://www.glastuinbouwwaterproof.nl/content/3Onderzoek/Recircul atie_potorchidee/7_Flyer_Watervoorziening.pdf (in Dutch).

Van Os, E. A. and Kromwijk A., 2014b. Recirculatie potorchidee. Flyer 10. Scenarioberekeningen stikstof emissie. Available at: http://www.glastuinbouwwa terproof.nl/fileadmin/user_upload/waterproof/Projecten/doc/Potorchidee/2014 _08_20_flyer_recirculatie_potorchidee_10_scenarioberekeningen_emissie.pdf (in Dutch).

Van Ruijven, J. P. M., van Os, E. A., Beerling, E., Blok, C., Janse, J., 2019. Towards zeroliquid discharge in hydroponic cultivation. Acta Hortic. 1242, 863-872.

Van Tuijl, B. A. J., van Henten, E. J. and van Os, E. A., 2005. Mobiele gerberateelt en toekomstige ontwikkelingen. A\&F rapport 330, 42p (in Dutch). 
Van Velden, P., 2014. Alles is gericht op een ziektevije teelt met hogere opbrengst. Onder Glas April 2014, 18-19. Available at: https://www.onderglas.nl/magazines/\#dflip-df _830/18/(in Dutch).

Van Weel, P. A., 2005. Movable gutters role in rose production. FlowerTech 8(7), 30-32.

Van Winsen, J., 2015. Teelt chrysant op water onder de loep. Nieuwe Oogst 11 April 2015. Available at: https://www.proeftuinzwaagdijk.nl/publicaties/Chrysant\%20op\% 20water\%2011-4-2015\%20Nieuwe\%20Oogst.pdf (in Dutch).

Vermeulen, T., 2009. Literatuurstudie chrysant los van de grond. Wageningen UR Glastuinbouw. Report 233, 60p (in Dutch).

Vermeulen, T., van der Linden, A. M. A. and van Os, E. A., 2010. Emissions of plant protection products from glasshouses to surface water in The Netherlands. (Rapport / Wageningen UR Greenhouse Horticulture/RIVM rapport; No. GTB1002/607407001). Bleiswijk: Wageningen UR Greenhouse Horticulture.

WFD, 2000. EU Water Framework Directive 2000/60/EC. Available at: http://ec.europa .eu/environment/water/water-framework/index_en.html

Zheng, Y. 2018. Current nutrient management practices and technologies used in North American greenhouse and nursery industries. Acta Hortic. 1227, 435-441. 